\title{
Lumen
}

Selected Proceedings from the Canadian Society for Eighteenth-Century Studies

\section{The Cultural Historian and the Garden}

\section{Michel Baridon}

Volume 19, 2000

Material Productions \& Cultural Construction

Culture matérielle \& Constructions discursives

URI : https://id.erudit.org/iderudit/1012313ar

DOI : https://doi.org/10.7202/1012313ar

Aller au sommaire du numéro

Éditeur(s)

Canadian Society for Eighteenth-Century Studies / Société canadienne d'étude du dix-huitième siècle

ISSN

1209-3696 (imprimé)

1927-8284 (numérique)

Découvrir la revue

Citer cet article

Baridon, M. (2000). The Cultural Historian and the Garden. Lumen, 19, 23-37. https://doi.org/10.7202/1012313ar

Copyright (c) Canadian Society for Eighteenth-Century Studies / Sociéte canadienne d'étude du dix-huitième siècle, 2000
Ce document est protégé par la loi sur le droit d'auteur. L'utilisation des services d'Érudit (y compris la reproduction) est assujettie à sa politique d'utilisation que vous pouvez consulter en ligne.

https://apropos.erudit.org/fr/usagers/politique-dutilisation/ 


\section{The Cultural Historian and the Garden}

Gardens are generally said to be 'a trendy subject' and I feel I should perhaps apologize for choosing them as a topic for this plenary address. For many people 'trendy' is just a synonym for 'superficial,' because snobs leave it to fashion to decide on what they like or dislike. Yet, as a cultural historian, I would like to put in a plea for snobs. They may be superficial but they are good indicators of what is modern in a given period. As eighteenth-century specialists, we all know Goldsmith's description of a snobbish conversation in The Vicar of Wakefield: 'The two ladies threw my girls into the shade; for they would talk of nothing but high-life and high-lived company; with other fashionable topics such as pictures, taste, Shakespeare and the musical glasses. ${ }^{1}$

We may smile, but the 'fashionable topics' of the two ladies were not so badly chosen after all: pictures were worth discussing in an age when a British school of painting was coming into its own at last; taste was one of the key words of the Palladian credo; Shakespeare was opening the way for Romantic drama, and the musical glasses were not indifferent to the great Mozart himself, since he once made use of them in a piece which, I must admit, has added little to his fame.

The snobs who pose as garden enthusiasts today are pointing to the direction from which the wind of innovation is blowing, and the wind of innovation keeps us all mentally alert. So let us ask ourselves first, why are gardens a popular topic? And second, what do gardens teach us about the past and, more particularly, about the Eighteenth Century? The first question I shall answer rather rapidly as I wish to concentrate on the second, the one with which I was invited to deal as a guest speaker.

Gardens are a popular topic because they have always been a popular topic. Ever since the days of Adam and Eve, gardens have been a matter of common conversation. Indeed, when Adam began to speak, he described his garden, giving names to all the plants and all the creatures he could see in it. In the primitive myths of most religions, in Egypt, Greece, Mesopotamia, India, China, Japan, fertility appears when the sky is separated from the earth, making life possible on the surface of our planet. As civilization develops gardens appear as the humblest and the 
most splendid artifacts. The poorest peasant has a garden because he must feed his family. The most ambitious princes have gardens - the royal plural - to lord it over their subjects, to please their mistresses, and to impress foreign ambassadors. Bacon says quite rightly: 'And a Man shall ever see that when Ages grow to civility and Elegance, men come to build stately rather than garden finely: as if Gardening were the greater perfection. ${ }^{2}$

To-day we still have kitchen gardens and ambitious princes, but things have changed and are changing everyday. Kitchen gardens tend to be the luxury of gourmets who grow their own tomatoes instead of buying substitutes - fresh from the hothouse - at the supermarket and, although princes and very wealthy people still have gardens, they do not - at least not always - reserve them for private enjoyment. Besides, large gardens have now become part of our townscapes, and town authorities spend large sums of money designing public parks whose shape and arrangements are discussed publicly and mentioned in the press. Paris has created more public parks since 1977 than in the century following the downfall of Napoleon III. Landscape architects who enter competitions submit projects which express their interest in new technologies and their wish to express the modernity of our age. La Villette is one example [FIG. 1]. The Parc André Citroën is another [FIG. 2]. The modern landscape artist now occupies a position which makes him come into contact with ecology, botany, city-planning, sociology, etc. He dominates the intellectual scene. In Geoffrey Jellicoe's words: 'The world has

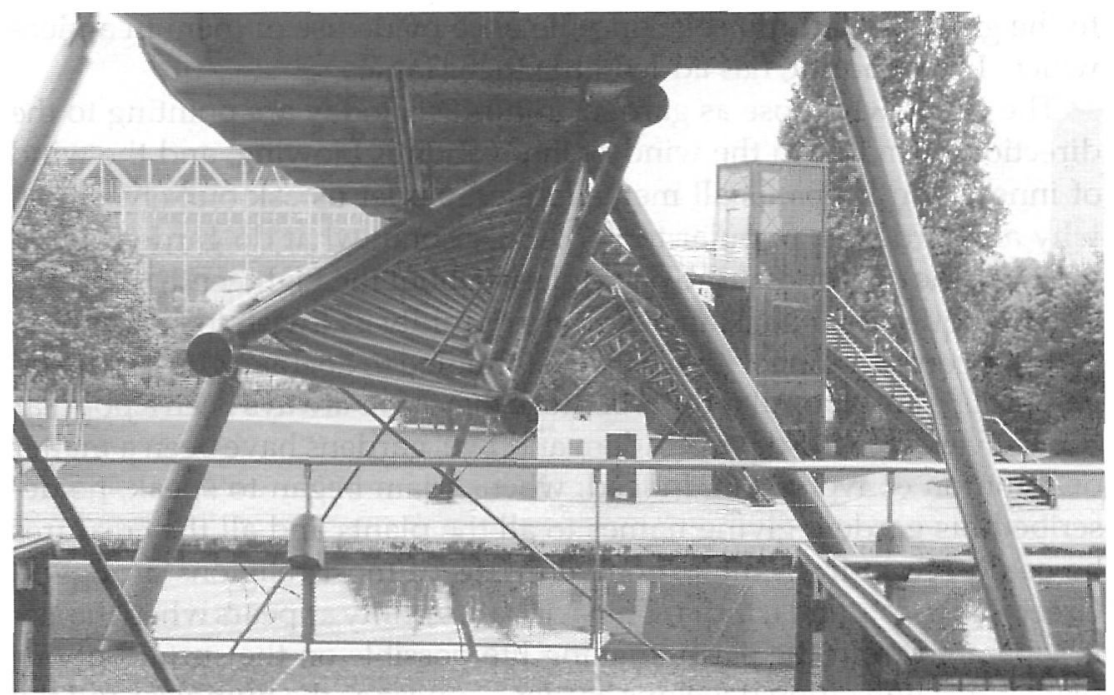

Figure 1 Le Parc de la Villette, Paris. (Author's photograph) 


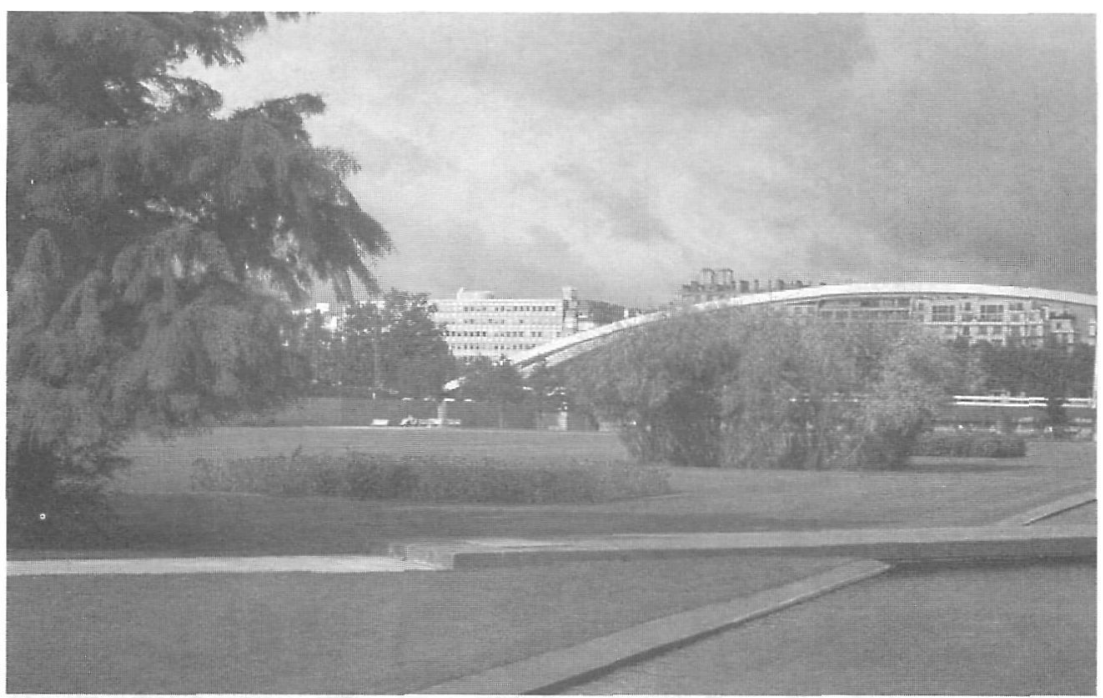

Figure 2 Le Parc André-Citroën, Paris. (Author's photograph)

moved into a phase when landscape design may well be recognized as the most comprehensive of the arts. ${ }^{\prime 3}$

The same Jellicoe, in Landscape of Man, presents wonderful photographs taken from satellites, showing the earth as we all see it now, a blue planet with a thin layer of vegetation. It is the realization that the layer is very thin indeed that makes us realize our natural heritage has become as vital to us as our cultural heritage. Landscape design reconciles the two and is, and was from the start, inseparable from garden art. I take it as a sign of the times that a review which has done much to open the world of gardens to academic learning, The Journal of Garden History, has recently changed its name to Studies in the History of Gardens and Designed Landscapes.

This is the ideal transition to introduce my second point, for the founder of the review I have just mentioned is John Dixon Hunt, whose books have shed light on the early development of the landscape garden in the Eighteenth Century. Indeed, the very terms 'landscape garden' and 'landscape gardener' date from our period as Humphrey Repton's trade card shows [FIG. 3] and this creates a strong link between Jellicoe's tribute to his profession and Horace Walpole's praise of garden art as the very image of the modernity of his time. ${ }^{4}$

The cultural historian cannot fail to notice the long filiation which links an artist who worked for the gentry and the nobility of Georgian England and a landscape gardener whose message is for all men over 


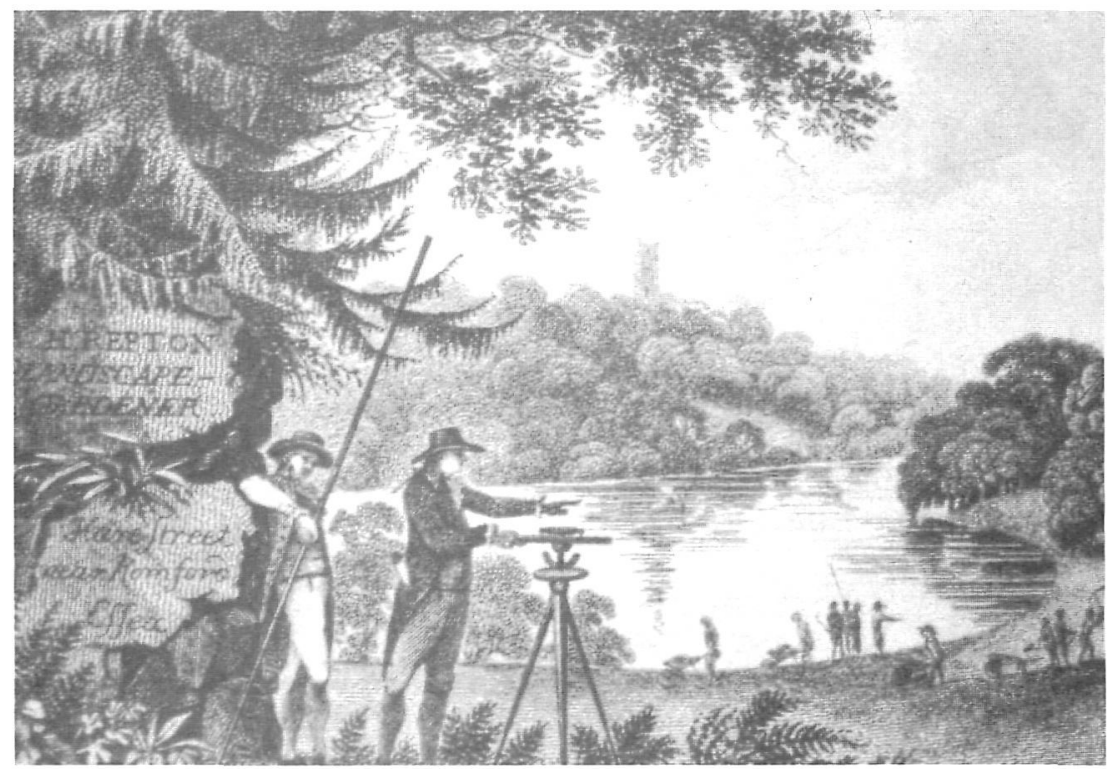

Figure 3 Repton's Trade Card. Engraving. (Victoria and Albert Museum, London)

the whole planet. And he will inevitably ask himself the question which is at the same time the joy and the bane of his intellectual life: But why did this happen?

I do not pretend to give a full and final answer to this question, but what I would like to do is to bring together social and intellectual history in order to show why a new type of garden began to appear in the country houses of Great Britain and why it rapidly spread over the whole continent and replaced the formal style which had hitherto set the tone. But before I do so, I would like to give a quick sketch of what one of the correspondents of The World called the rapid progress of this fine enthusiasm..$^{5}$ Before one sets out to find causes, one must have a clear view of what actually happened.

The first open manifestation of the new taste for landscape gardening is to be found in a letter sent by Sir John Vanbrugh to Sarah, Duchess of Marlborough. You may know the story. She wished to demolish the ruins of Woodstock Manor which stood on the grounds of Blenheim [FIG. 4]. Vanbrugh rose in defence of the old Gothic ruins and wrote:

It was raised by one of the bravest and most warlike of the English kings and though it has not been famed as a monument of his arms it has been tenderly regarded as the scene of his affections.... But if the historicall argument stands 
in need of assistance there is still much to be said on other considerations.... were the inclosure filled with trees, principally fine yew trees and hollies promiscuously set to grow up in a large thicket, so that all the building left (which is only the habitable part and the chapel) might appear in two risings amongst them, it would make one of the most agreeable objects that the best of Landskip painters can invent. ${ }^{6}$

This is an astonishing letter, for not only is the whole gothic revival presented here in a nutshell, but Vanbrugh points out in a single sentence that the landscape garden is inseparable from landscape painting. Again and again do we find in the Eighteenth Century, this central idea expressed in English, in French, and in German. I give a few famous examples:

Pope: "[The genius of the place] paints as you plant"7

Watelet: "Rapprochons-nous du peintre " $^{8}$

Carmontelle: "L'agrément d'un jardin naturel est d'y trouver à chaque pas des tableaux" ${ }^{\prime \prime}$

Delille: "Soyez peintre"

Jean Marie Morel: "Cette nation pensante [1'Angleterre] en substituant le crayon à la règle et au compas l'a élevé [1'art des jardins] au rang des arts libéraux"11 Hirschfeld: "Aucun [des arts libéraux] n'est allié à [l'art des jardins] d'aussi près que la peinture ${ }^{\prime 12}$

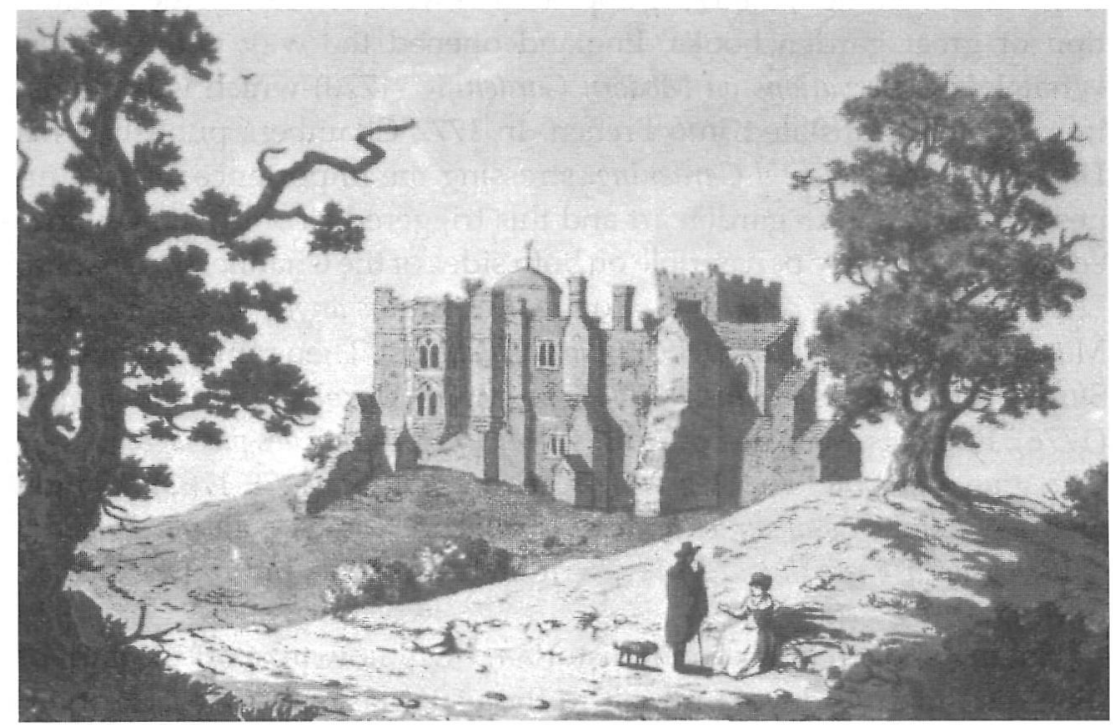

Figure 4 Woodstock Manor. Drawing 1714. (British Library, London) 
Vanbrugh's letter to the Duchess of Marlborough must be considered as a manifesto whose effects were soon to be visible in the English landscape.

In the 1730s, the new fashion was well on the way. Burlington's association with Kent, who was originally a painter, developed the connection between Palladian architecture and the landscape garden. Chiswick was described by Pope, the most famous poet of the age, and Sir Thomas Robinson wrote: 'A general alteration of some of the most considerable gardens in the country has begun after Mr Kent's notion of gardening, viz. to lay them out and work without either level or line. ${ }^{13}$

In the 1750s, twenty years later, Stowe had become the English Versailles. It was the place to visit, since Vanbrugh, Kent and Capability Brown had done work in it. Lord Cobham appeared as an English Maecenas and William Pitt (who had married into the Temple family and was often there) as a new Scipio Africanus. Art, politics, history and architecture contributed to make the place the most famous garden in England and the very image of what was new in the field.

In the 1780s, thirty years later, the 'rapid progress of this fine enthusiasm' had done wonders. In England, it was not only the 'fine majestic paradise of Stowe' which attracted the attention of an ever increasing public. Landscape poets like Shenstone had created a new literary genre thanks to the ferme ornée; Gilpin was on his picturesque tours; Horace Walpole had acquired international fame as a Gothic revivalist and as the first historian of the garden as a new and essential art form. As if all this was not enough, the 1770s appeared as wonder years in the production of great garden books. England opened the way with Thomas Whately's Observations on Modern Gardening (1770) which was almost immediately translated into French. In 1772 Chambers published his Dissertation on Oriental Gardening, stressing the importance of the Chinese contribution to garden art and this triggered a controversy whose echoes were clearly perceptible on both sides of the Channel (Chabanon, Lettre sur les jardins anglais; Le Rouge, Des jardins anglo-chinois; William Mason, An Heroic Epistle to Sir William Chambers). Then came Duchesne's Sur la Formation des jardins (1775); Jean-Marie Morel's Théorie des jardins (1776); François-René de Girardin's De la Composition des paysages (1777); Christian Hirschfeld's Théorie de l'Art des Jardins (1779-1783); Claude Henri Watelet's Essai sur les Jardins (1779); and Horace Walpole's History of the Modern Taste in Gardening, written before 1771 but not published until 1780.

Having spoken as a garden historian, I will now take off the garb of the green man to devote myself to the usual tasks of that Jack-of-alltrades, the cultural historian, who is still wondering why all this hap- 
pened and why the whole of Europe imitated England in the second half of the Eighteenth Century.

In approaching difficult questions such as this, I must admit that there is no straightforward answer. I believe in a system of interdependent causes reflecting on each other and all developing at the same time. Two of them seem to be predominant: politics and the world picture (as it exists in the imagination of artists not always familiar with the world of science yet deeply receptive to the changes occurring in scientific thinking).

Let me begin with politics. It may seem strange to establish intellectual connections between politics and the landscape but they did exist in the mind of Thomson ${ }^{14}$ and Addison as shown by the following quotations from The Spectator $\left(\mathrm{N}^{\circ} 414\right)$ and from The Tatler $\left(\mathrm{N}^{\circ} 161\right)$, the one written in praise of improvement of private property, the other connecting the straight line with despotism:

Why may not a whole estate be thrown into a kind of garden by frequent plantations that may turn as much to the profit as to the pleasure of the owner.

This river (the Rhone river in Switzerland) after having made its progress through those free nations stagnates in a huge lake at the leaving of them and no sooner enters the reigns of slavery but runs through them with an incredible rapidity and takes its shortest way to the sea.

In other words, French absolutism imposes straight lines even on rivers whereas post Glorious Revolution England gives freedom even to nature. The same contrasted parallels between despotism and the formal garden on one hand, and liberty and the landscape garden on the other, occur again and again in the garden literature of the period. They find an echo in Repton's praise of the system of limited monarchy in his Sketches and Hints on Landscape Gardening published during the Napoleonic wars. He comments on the English constitution founded, he says, on

the happy medium between the wilderness of nature and the stiffness of art; in the same manner as the English constitution is the happy medium between the liberty of the savages and the restraints of despotic government; and so long as we enjoy the benefit of these middle degrees, between the extremes of each, let experiments of untried theoretical improvement be made in some other country. $^{15}$

What Repton does not say is that many country gentlemen were then requiring his services to landscape newly enclosed lands. The money 
won by the rising industrialists, bankers, and traders was often invested in land, and upstarts had to have gardens if they were to cut a figure among polite people. Repton gave his profession a name at a time when the number of enclosure acts was on the increase, rising to the unprecedented figure of nine hundred and six between 1800 and $1810 .{ }^{16}$

The contrast between France and England must be stressed here. While in France absolutism and the nobility fell together in 1792-94, in England the Glorious Revolution limited the power of the king and increased the influence of the nobility. The whole political machinery being land-based, the Lords were powerful in the Commons as well as in their own House. Younger sons and country squires composed a majority in the Lower House and their loyalties were often to the country where houses such a Castle Howard, Wilton House, or Chatsworth stood as active seats of power.

Such a system favoured the landscape garden because it imparted to the house a kind of homely aloofness still to be found in the gracious welcome given to tourists by the English gentry of our time. Besides, the levelling character of absolutism had always run counter to the interests of the nobility: Richelieu had decapitated Cinq-Mars and de Thou, Lord Russell was accounted one of 'the whig martyrs.' The gardens of Versailles were the very image of a country rationally organized by the superior genius of the monarch and by the power delegated by Colbert to the Intendants. This highly centralized system had deprived the nobility of its immemorial prerogatives, said Boulainvilliers and SaintSimon who were no friends of Louis XIV. Boulainvilliers, like Montesquieu a member of the Noblesse de robe, admired the English system of government and called upon the historians of the medieval period to retrieve the political treasures which lay buried in the medieval chronicles.

Such were also the views of the English nobility as expressed by Burke when he wrote to Lord Richmond:

You people of great families and hereditary trusts or fortunes are not like such as I am who are ... but annual plants .... You are the great oaks that shade a country and perpetuate your benefits from generation to generation. ${ }^{17}$

In the same letter, Burke described the country houses of the nobility and gentry as 'the public repositories and offices or record of the constitution.' Never was the poetic link between the Brownian landscape and the power of the nobility so powerfully expressed in Georgian England.

But it was not only the shade of the oaks which gave a forceful expression to the historic character of aristocratic power. The statues and the temples which were to be seen here and there on the grounds were 
cultural emblems serving the same purpose. At Stowe the Gothic Temple was erected in praise of the Saxon system of government which struck a happy balance between the prince, the nobility and the people. Not far from it stood the Temple of Ancient Virtue in which the legislators of Rome and Athens also represented a system of government in which the power of the consuls was limited by the Senate and by the comitiae. Both the Gothic Temple and the Temple of Ancient Virtue thus extolled a system of government uniting Monarchy, Aristocracy and Democracy, as did the invaluable English constitution which lodged the supreme power in 'the King in Parliament,' another name for the sacrosanct trinity: King, Lords and Commons.

The symbolic quality of such emblems is enough to prove, I believe, that politics did play a part in the emergence of the English landscape garden. But the cultural historian cannot limit himself to what was known and said at the time when the temples were built. He also has to account for the fact that the landscape garden also triumphed in countries where despotic power had not been limited. Madame de Pompadour gave full freedom to the vegetation of her parks but her royal lover believed and said that the crown was the fountainhead of power. What factors, then, can explain the spreading of the landscape garden all over Europe?

The development of landscape gardening and the intellectual history of the period reveal striking parallels. In 1709, when Vanbrugh tried to save the ruins of Woodstock, Locke had been dead for five years but his Treatise concerning Human Understanding had already been translated into French and Latin, and this made it accessible to the intelligentsia of Europe. So was Newton's Opticks published in English in 1704 and translated into Latin three years later whereas the Principia, originally published in Latin, had to wait until 1729 before it was translated into English and until 1756 before it appeared in French.

In 1709, Boyle, who had done much to make chemistry one of the leading sciences of the century, had been dead for eighteen years but was considered to have played a full part in the rise of the Royal Society to European fame. He was known to have had Locke's collaboration when he composed his History of the Air and he had formulated the basic tenets of the experimental method in the Philosophical Transactions.

Burnet was still alive. His Sacred Theory of the Earth whose publication had begun in the early sixteen eighties was widely read and discussed. Burnet's theory is well-known. He described the formation of the earth in terms which were theological enough to connect geology with the Bible yet scientific enough to win Buffon's attention later. According to Burnet, the earth was a perfect sphere until God had broken its smooth surface to punish Adam and Eve. The globe had lost its geometrical form 
when the water which lay under its crust had flooded most of its surface. The continents as we see them, he maintained, were but the ruins of the earth in its once perfect form. Yet these ruins had their beauty because they made man tremble at the thought of God's irrepressible power. Burnet's theory was popular because the world picture had changed. And it is because the world picture had changed that Vanbrugh wished to keep ruins on the grounds of Blenheim Palace. Ruins had already been much in favour at the Renaissance but now they embodied the modernity of the age. The rise of English science was connected with the experimental method and with the empirical school in philosophy. It is this connection which changed the world picture of the age and which caused ruins, the emblem of decay, to become the image of modernity.

The Newtonian universe had very little in common with the mechanism which had prevailed in the Seventeenth Century. As Voltaire said, 'You leave Paris believing that the world is a plenum, you arrive in London and you find it empty. ${ }^{, 18}$ By Paris, of course, he meant the scientists who still adhered to the Cartesian world picture. But it was not only the Cartesian philosophy which was called to task by Newton, it was the whole mechanistic philosophy of the Seventeenth Century, a philosophy in which forces acted on solids by direct action, as if the transmission of motion was by pulleys, cogged wheels and vortices. In the closing sentence of his introduction to Book III of his Ethics, 'On the Origin and the Nature of Sentiments,' Spinoza said 'I shall consider human actions as if they were lines, planes and solid bodies.' If such was the ambition of a philosopher, no wonder that gardens had geometrical forms and water jets were made to soar everywhere as visible demonstrations of the geometrical trajectory followed by bodies when projected into space.

It was not so with Isaac Newton. Attraction to him was a mysterious force, not transmitted by physical agents, as he stated in the opening sentence of Principia:

I wish we could derive the rest of the phenomena of nature by the same kind of reasoning from mechanical principles, for I am induced by many reasons to suspect that they may all depend upon certain forces by which the particles of bodies by some causes hitherto unknown, are either mutually impelled towards one another and cohere in regular figures or are repelled and recede from one another.

Besides being composed of particles, bodies were not only solids with definite geometrical forms; they could be penetrated by other bodies and their nature could change. In a very important passage of his Opticks Newton wrote: 
Seeing therefore the variety of Motion which we find in the World is always decreasing, there is a necessity of conserving and recruiting it by active Principles such as are the cause of Gravity, by which Planets and Comets keep their Motion in their Orbs, and Bodies acquire great Motion in falling; and the cause of Fermentation by which the Heart and the Blood of Animals are kept in perpetual Motion and Heat; the inward parts of the Earth are constantly warmed, and in some Places grow very hot; Bodies burn and shine, Mountains take fire, the Caverns of the Earth are blown up, and the Sun continues violently hot and lucid and warms all things by Light. ${ }^{19}$

If fermentation was one of the two 'active principles' which kept the universe in motion, chemistry must be considered a key science. This induced major transformations of the world picture because chemical reactions changed the nature of bodies. A solid could become a gas, and gasses, having no shape, could not be described in geometrical terms. The mechanistic world picture could no longer provide adequate representations for the phenomena described by scientists. The downfall of Cartesianism is inseparable from the emergence of chemistry as a new science. It was by studying chemistry that Diderot came to assert that geometrical forms did not exist in nature and that only the life sciences could provide man with proper means to make sense of the world as he saw it. What Diderot openly said was instinctively perceived by his contemporaries who turned away from the symmetry, the geometry and the formality of the preceding age. The landscape garden with its flowing lines and its irregularity corresponds to Hogarth's winding line of beauty and to his emphasis on the supple character of the skin.

No less important than the rise of chemistry was the emergence of psychology as a major intellectual field of scientific research. Locke's Essay concerning Human Understanding was read and discussed all over Europe and, although Locke proposed no theory of aesthetics, his followers did so, for reasons which can be easily understood. He presented mental life as a continuum by which the mind processed the sensations originating in our sense organs when they were hit by particles coming from the external world. Man's ideas, however metaphysical, had their origin in the living tissues which transmitted sense impressions to the brain and the brain stored them in the memory in order to combine them into complex ideas. The whole process, Locke explained, was accompanied by pleasure and pain, two modes of sensation which were interdependent since a decreasing pleasure turned into a pain, and vice versa. Here again, the impression is one of fluidity, and the emphasis is definitely on the life sciences. Locke was a medical doctor who strove to describe 'the way of ideas' as one of the functions of a living body. 
Such a theory of the human mind agreed with the landscape garden much better than its formal counterpart. The visitor following a winding alley is provided with a wealth of sensations he cannot find in a straight one. He has the sun now on his right hand side, now on his left. He finds himself in the shade, then in the light. Even sounds and smells vary as he gets nearer a wood or a river, and then is led further away. Pleasure is changed into pain as he discovers a ruin or a grave, but, as he goes along, the unexpected sight of the 'smiling plain' may well cheer him up again. Besides, he never sees the whole garden from a terrace as was almost always the case with the formal style. He is at liberty to roam as much as he likes and does not acquire a full knowledge of the garden until he has finished his perambulation.

Here again, we find striking parallels with the scientific movement. Newton and his colleagues of the Royal Society were experimentalists who attributed their successes to their method. Instead of starting from axioms, like the geometricians, they established the primacy of observation over theory. The true scientist was a patient observer who compiled histories of his experiments, collating indications of time and place as often as he could. These indications he called particulars. Locke worked with Boyle on a History of the Air and he kept records of the temperature, the winds, the barometric pressure, the shape of the clouds for months five times a day - no mean achievement in a country like England. But Locke also said in his Introduction to the Essay concerning Human Understanding, that he had used the 'historical plain method' to compose his treatise, and this refers us to the landscape garden again. If the most important philosopher of the period favoured a method in which nothing must be defined a priori and everything must be considered in relation to time, the landscape garden must have appeared in a new light to the thinking visitor. It was not only a place where he could discover all the senses of the term sensibility but was also the place where he was shown how to acquire a true knowledge of nature.

The changes intervening in the world picture and in the theory of knowledge as evidenced in gardens also affected literature. What is Defoe's Tour thro' the Whole Island of Great Britain if not the history of England and Scotland? And isn't Robinson Crusoe a history of the discovery of an island by a sailor who keeps a faithful record of the climate, the fauna, the flora, the tides, the tempests and the living conditions of the natives? The structure of the landscape garden can help us understand why Fielding uses irregular chapters (many of which have time indications in their titles) to give his readers freedom as they perambulate the world in search of the true knowledge of human nature. It can also help us understand why Thomson found blank verse particularly appropriate for The Seasons. By doing away with rhyme, by the frequent use of 
enjambments, he could develop an ample, flexible rhythmic pattern which ideally suited his descriptions of landscapes.

As I do not wish to be too long, I shall now leave the first decades of the Eighteenth Century and go straight to its last three decades, when landscape gardening became really European and inspired some of the best books ever written on the subject, books which were not only proper to garden literature (as for example those of Whately, Morel, Carmontelle, Walpole, Mason and Hirschfeld) but which also made landscapes essential to the writing of poetry and of fiction (for example, the Gothic Novel and the works of Rousseau and Goethe).

After the death of Montesquieu, Rousseau appeared more and more as the most influential figure on the intellectual scene, and he was known as 'l'homme de la nature et de la vérité.' But it is precisely nature as a concept that we need to consider if we want to understand the problematic which confronted the intellectuals of the age. This problematic was dependent on a concept created by Turgot, then taken up by Rousseau and later by Kant, the concept of perfectibility. It was preeminently what we would call today a left-wing concept created by Turgot on the same model as expansibility, a term which he used as a chemist to describe the nature of gasses. Again, we find chemistry at the centre of the picture.

The perfectibilists showed man always striving to change his living conditions and changing his own nature in an endless process which had begun with primitive man and was leading towards the greatest possible happiness for all. This made a long time scheme come into play for it took 'des multitudes de siècles,' as Rousseau said, to pass from one stage of development to the next. Perfectibility made human nature a plastic entity which had little in common with the immutable human nature described once and for all by the unsurpassable models of antiquity. Rousseau's succession of centuries turned the imagination of artists towards the early stages of human history, the times when human nature was pure and uncorrupted. Only Nature in its virgin state provided images of this blessed condition of political innocence. Hence Rousseau's interest in Robinson Crusoe; hence also his love of the landscape garden and the homage paid to Shenstone at Ermenonville. The contemplation of a landscape conveyed ideas of primitive equality; it could effect individual regeneration.

In the 1760s and 1770s, when France and Germany adopted the English landscape garden, Rousseau's fame had begun to spread in Europe. He had his partisans among the intelligentsia, some of whom were fermiers généraux with enough money to create such gardens as the Désert de Retz or Méréville. They saw the landscape as a place of enchantment where one could see the felicity to come as well as the image of primitive times. Hence the grottoes and huge rocks whose mass 
was left intact by time. Hence also the fabrics evocative of China or Tartary, the monuments to Cook and Bougainville, surrounded by landscapes whose poetry was subtly enhanced by painters like Hubert Robert or Carmontelle.

Such places can never be forgotten, and the cultural historian will be satisfied if he has been able to add an intellectual note to the pleasure they offer when we visit them. I hope I have shown that the development of the landscape garden was one of the major achievements of the Eighteenth Century. I hope I have also shown that, while politics played a part in its early history, the rise of the life sciences was the most constant factor in their development. It may be strange perhaps to connect laboratories with the landscape, but artists have their own ways to create fashions by imbibing what looks to them new and true. And, once the human imagination takes flight, it will always display its amazing fertility. No finer term could be found to end a talk on gardens.

\section{MICHEL BARIDON \\ Université de Bourgogne}

[Editorial Note: The present article is an abbreviated version of Professor Baridon's conference presentation. Members who wish to read M. Baridon's fuller treatment of the subject are referred to his award-winning book, Les Jardins: Paysagistes-Jardiniers-Poètes (Paris: Robert Laffont, 1998).]

\section{NOTES}

1 The Vicar Of Wakefield (London: Everyman, 1956), p. 46.

2 'Essay of Gardens,' The Works of Francis Bacon, ed. Spedding, Ellis and Heath (London, 1857), vol. III, p. 150.

3 Geoffrey and Susan Jellicoe, The Landscape of Man (London: Thames and Hudson, 1995), p. 7.

4 On Walpole's praise of gardens, see John Dixon Hunt and Peter Willis (eds.), The Genius of the Place: The English Landscape Garden 1620-1820 (Cambridge, MA: MIT Press, 1992), p. 313.

5 The World, $\mathrm{N}^{\circ}$ 118, for Thursday, April 3, 1755.

6 See The Genius of the Place, p. 121.

7 Alexander Pope, Epitre à Burlington, CEuvres Completes (Paris: Devaux, 1796), translated by the abbé de La Porte, line 64. 
8 Claude-Henri Watelet, Essai sur les jardins (Paris: de Prault, 1774), p. 109.

9 Carmontelle, Le Jardin de Monceau (Paris, 1779), p. 5.

10 Delille, Les Jardins (Paris: Hiard, 1832), chant 1, p. 31.

11 Jean-Marie Morel, La Théorie des jardins, Préface, 2nd ed. (Paris: Panckoucke, 1802), vol. 1, p. cxiv.

12 Christian Hirschfeld, Théorie de l'Art des Jardins, 5 vols (Leipzig: Reich, 1779-1785), I, p. 168.

13 Morris Brownell, Alexander Pope and the Arts of Georgian England (Oxford: Clarendon Press, 1978), p. 175.

14 See his description of Hagley in The Seasons.

15 Sketches and Hints of Landscape Gardening, ed. Loudon (London: Longman, 1840), p. 61. The passage is to be found in a Letter to Uvedale Price given as an appendix.

16 Paul Mantoux, The Industrial Revolution in the Eighteenth Century (London, 1961), p. 142.

17 Burke to Lord Richmond, 15 Nov. 1772, The Correspondence of Edmund Burke, ed. T.W. Copeland et al. 10 vols (London, 1960), vol. 2, p. 377.

18 'Quatorzième Lettre: Sur Descartes et Newton,' Lettres Philosophiques.

19 Newton, Opticks, ed. E. T. Whittaker (New York, 1931), Book III, Part I, p. 399. 